\title{
Nitrate, ammonium and urea nitrogen as fertilizers for wheat and rye in a field experiment
}

\author{
ANTTI JAAKKOLA \\ Agricultural Research Centre, Department of Agricultural Chemistry and Physics, \\ 01300 Vantaa 30
}

\begin{abstract}
In a five-year field experiment on a well-limed sandy soil five nitrogen fertilizers were compared. They were urea, ammonium sulphate, calcium nitrate, calcium ammonium nitrate and a mixture of ammonium sulphate and calcium nitrate. The crops in successive years were spring wheat, winter rye, winter wheat, spring wheat and winter rye.

The average yield level was not different because of different fertilizers, but in individual years some differences were found. Average contents of nitrogen and calcium in grain and straw, however, showed a slight superiority of calcium nitrate to ammonium sulphate. Other fertilizers did not deviate significantly from either of these, Placement vs. broadcasting, application time and rate of fertilizer nitrogen were also investigated. These factors did not affect the differences between fertilizers.

The soil-acidifying effect of the fertilizers decreased in the order: ammonium sulphate, urea, mixture of $\mathrm{AS}$ and $\mathrm{CN}$, calcium ammonium nitrate. Calcium nitrate had no effect on soil acidity.
\end{abstract}

\section{Introduction}

In Finland calcium ammonium nitrate is the most common straight nitrogen fertilizer. Calcium nitrate has formerly been widely used for agricultural crops, but in recent years its importance has decreased and today it is rarely used. The utilization of urea has, on the other hand, increased to a remarkable extent. In addition to these, small amounts of other nitrogen fertilizers are used, among others ammonium sulphate. Ammonium sulphate is produced in Finland as a by-product of the cobalt industry in quantities many times in excess of its present utilization as fertilizer. However, the main part of fertilizer nitrogen, about $\mathbf{7 5}$ per cent, is given in multinutrient fertilizers together with phosphorus, potassium, and in some of them, also other nutrients. The nitrogen in these fertilizers is both in ammonium and in nitrate forms in varying ratios. Thus, from this point of view it is also important to know the differences in the effects of those nitrogen forms.

Different forms of fertilizer nitrogen have been compared earlier by several investigators, in Finland e.g. by SAlonen and HonkavaAra (1954, 1970) 
and Pessi et al. (1971 a, b). However, the above-mentioned forms of fertilizer nitrogen, i.e. nitrate, ammonium, ammonium nitrate and urea have not all been compared together in the same experiment. The aim of this study was to perform this on a well-limed sandy soil under cereal growing. Because winter cereals are an important object in the use of straight nitrogen fertilizers they were grown in three out of five years of the experiment.

\section{Material and methods}

The fertilizers compared in this stydy were:

1. Urea, $46 \% \mathrm{~N}$ totally in amide from

2. $\mathrm{AS}=$ ammonium sulphate, $20.5 \% \mathrm{~N}$ totally in ammonium form

3. $\mathrm{AS}+\mathrm{CN}=$ mixture of ammonium sulphate and calcium nitrate, $17,5 \% \mathrm{~N}$ as ammonium and nitrate nitrogen in equal amounts

4. $\mathrm{CAN}=$ calcium ammonium nitrate, $26-27.5 \% \mathrm{~N}$ as ammonium nitrate

5. $\mathrm{CN}=$ calcium nitrate, $\mathbf{1 5 . 5} \% \mathrm{~N}$, mainly in nitrate form. Content of ammonium nitrogen 1 per cent.

The urea, calcium ammonium nitrate and calcium nitrate were usual commercial products. The ammonium sulphate was a by-product of the cobalt industry containing $350 \mathrm{mg} / \mathrm{kg}$ Co. The mixture of ammonium sulphate and calcium nitrate was composed by mixing the fertilizers immediately before application in proportions of 40 and 60 per cent, respectively.

The soil on the experimental field was a sandy soil with the following characteristics:

\begin{tabular}{|c|c|c|}
\hline & plough layer & subsoil \\
\hline Clay fraction $(<2 \mu \mathrm{m}), \% \ldots \ldots$. & 14 & 11 \\
\hline Organic carbon, $\%$................. & 3.8 & 0.7 \\
\hline CEC, mval/100 g ................... & 20 & - \\
\hline Total nitrogen, $\mathrm{mg} / \mathrm{g} . \ldots \ldots \ldots \ldots \ldots$ & 2.2 & - \\
\hline $\mathrm{pH}_{\mathrm{CaCl}_{2}} \ldots \ldots \ldots \ldots \ldots \ldots \ldots$ & 6.2 & 6.0 \\
\hline 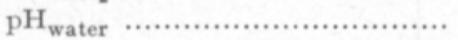 & 6.8 & 6.6 \\
\hline
\end{tabular}

The plough layer was $25 \mathrm{~cm}$ deep. The subsoil sample was taken from the layer between 25 and $35 \mathrm{~cm}$.

Incubation experiment. In order to get an idea of what happens in the soil to the nitrogen derived from the different fertilizers an incubation experiment was performed. Lots of $200 \mathrm{~g}$ air-dry soil representing the plough layer of the experimental field were weighed into 0.51 plastic pots. Amounts containing $100 \mathrm{mg}$ of nitrogen of each fertilizer were weighed into eight pots and mixed with the soil. In addition eight pots were left without fertilizer as controls. Four pots of each treatment were watered with $50 \mathrm{ml}$ of water, the other four received double amounts water to get low or high soil moisture levels, respectively. The low moisture corresponded to about one bar tension, the high moisture corresponded to about 0.01 bar. The pots were covered with paper which was occasionally removed to prevent anaerobic conditions. The pots were watered when necessary to keep the moisture at the initial level. 
After a period of 24 days the $\mathrm{pH}$ and the ammonium and nitrate nitrogen were determined in the soil. For the $\mathrm{pH}$ determination $10 \mathrm{~g}$ of wet soil in an airdry state was suspended with $25 \mathrm{ml}$ of $0.01 \mathrm{M} \mathrm{CaCl}_{2}$ solution. For ammonium and nitrate determinations the same amount of soil was shaken with $100 \mathrm{ml}$ of $0.5 \mathrm{~N} \mathrm{~K}_{2} \mathrm{SO}_{4}$ solution for one hour. Ammonium and nitrate were determined in the filtered solution potentiometrically by means of an ammonia and a nitrate electrode, respectively.

The field experiment was established in 1972 on the soil whose characteristics are given above. The field was divided into four blocks. Each block consisted of three main plots containing five subplots. Between and outside the main plots there were in all fifteen control plots, which received no nitrogen fertilization. The size of the subplot as well as the control plot was $3.5 \mathrm{~m}$ by $20 \mathrm{~m}$.

The experimental factors in the main plots consisted of different methods of fertilizer application, application times and rates of fertilization $(\mathrm{kg} / \mathrm{ha} \mathrm{N})$ as follows:

$\begin{array}{llccc}\text { Year } & \text { Crop } & \text { A } & \text { B } & \text { C } \\ 1972 & \text { Spring wheat } & 75, \text { placed } & 150, \text { placed } & 150, \text { broadcasted } \\ 1973 & \text { Winter rye } & 75 \text {, broadcasted } & 0 & 0 \\ 1974 & \text { Winter wheat } & 75 \text {, broadcasted } & 75 \text {, broadcasted } & 75 \text {, broadcasted } \\ 1975 & \text { Spring wheat } & 100, \text { placed } & 100 \text {, placed } & 100 \text {, placed } \\ & & \text { a } & \text { b } & \text { c } \\ 1976 & \text { Winter rye } & 75, \text { broadcasted } & 75 \text {, broadcasted } & 75 \text {, broadcasted } \\ & & \text { Nov. } 1975 & \text { Early May } & \text { Late May }\end{array}$

The treatments $\mathrm{A}, \mathrm{B}$ and $\mathrm{C}$ were randomized among the three main plots of each block. For the last experimental year the randomization was repeated with the treatments $\mathrm{a}, \mathrm{b}$ and $\mathrm{c}$. The placement was done to a depth of $8 \mathrm{~cm}$ in rows $16 \mathrm{~cm}$ apart. The times of nitrogen application for winter rye in 1976 were 30.11. 1975 (a), 9.5. 1976 (b), and 25. 5. 1976 (c).

The treatments arranged for the subplots were the five sources of fertilizer nitrogen listed above. These treatments were randomized within each main plot.

The experimental crops were sown and harvested at the following dates:

\begin{tabular}{lrc} 
& \multicolumn{1}{c}{ sown } & harvested \\
Spring wheat $\ldots \ldots .$. & 17.5 .72 & 18.8 .72 \\
Winter rye $\ldots . . . .$. & 9.9 .72 & 30.7 .73 \\
Winter wheat $\ldots \ldots .$. & 5.9 .73 & 26.8 .74 \\
Spring wheat $\ldots \ldots .$. & 9.5 .75 & 27.8 .75 \\
Winter rye $\ldots \ldots \ldots .$. & 2.9 .75 & 26.8 .76
\end{tabular}

An annual basal dressing of 500 (years 1972-74) or 600 (years 1975-76) $\mathrm{kg} / \mathrm{ha}$ of ammoniated PK fertilizer containing $2 \% \mathrm{~N}, 7.4 \% \mathrm{P}$ and $12.5 \% \mathrm{~K}$ was broadcasted and mixed into the soil by harrowing before sowing.

The plots were harvested with a combine harvester to a stubble height of ca. $10 \mathrm{~cm}$. The harvested area varied in different years between 50 and 60 sq.m per plot. The threshed grain was weighed immediately. The straw was baled with a pick-up baler from every plot separately and weighed. 
Immediately after weighing grain and straw samples were taken from each plot. The dry matter content was determined in a subsample for calculation of the dry matter yield of each plot. The main part of the sample was allowed to dry to an air-dry state. Total nitrogen was determined by Kjeldahl digestion. Potassium, calcium and magnesium were determined by atomic absorption and phosphorus colorimetrically in an acid extract of ashed (at $500^{\circ} \mathrm{C}$ ) plant material.

In addition to the yearly sampling of grain and straw, the plant stand of the first experimental year was sampled twice at one-month intervals from the sowing. The plants were cut just above soil surface. The sampled area was 0.5 sq.m on each plot and consisted of two couples of sowing rows from the opposite ends of a plot. The samples were allowed to dry to an air-dry state, and were weighed and analyzed for nitrogen, potassium and phosphorus like the grain and straw samples.

Soil samples representing separate plots were taken and the $\mathrm{pH}$ determined as follows:

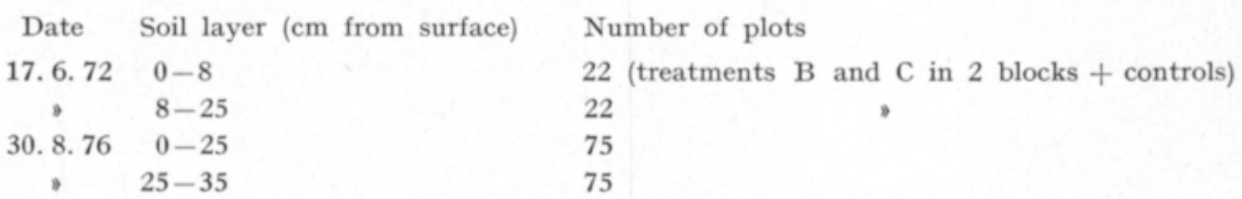

Every sample consisted of at least three subsamples taken from different parts of the plot. The samples were allowed to dry to an air-dry state in the laboratory (ca. $20^{\circ} \mathrm{C}$ ), sieved through a $2 \mathrm{~mm}$ sieve and homogenized. In the samples taken in 1972 the $\mathrm{pH}_{\mathrm{CaCl}_{2}}$ was determined as in the incubation experiment. In 1976 the $\mathrm{pH}$ was determined in water suspension at a soilwater ratio of $1: 2.5$ on volume basis.

The results were tested statistically by analysis of variance. The significance of differences between individual means was tested with Tukey's procedure.

\section{Results}

\section{Incubation experiment}

When incubated for 24 days in dry or wet soil at an application rate of $\mathbf{5 0 0}$ mg of fertilizer nitrogen per $\mathrm{kg}$ of soil the following $\mathrm{pH}_{\mathrm{CaCl}_{2}}$ values and ammonium and nitrate nitrogen contents $(\mathrm{mg} / \mathrm{kg})$ were obtained:

\begin{tabular}{|c|c|c|c|c|c|c|}
\hline & & dry soil & & & wet soil & \\
\hline & $\mathrm{pH}$ & $\mathrm{NH}_{4}-\mathrm{N}$ & $\mathrm{NO}_{3}-\mathrm{N}$ & $\mathrm{pH}$ & $\mathrm{NH}_{4}-\mathrm{N}$ & $\mathrm{NO}_{3}-\mathrm{N}$ \\
\hline Without fertilizer ........... & 6.2 & 10 & 20 & 6.5 & 20 & 0 \\
\hline 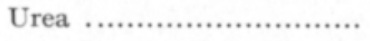 & 5.1 & 20 & 430 & 6.8 & 340 & 10 \\
\hline 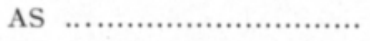 & 4.9 & 150 & 300 & 6.3 & 420 & 0 \\
\hline $\mathrm{AS}+\mathrm{CN} \ldots \ldots \ldots \ldots \ldots \ldots \ldots \ldots \ldots$ & 5.2 & 20 & 420 & 6.3 & 200 & 150 \\
\hline CAN $\ldots \ldots \ldots \ldots \ldots \ldots \ldots \ldots \ldots \ldots \ldots \ldots \ldots \ldots \ldots \ldots \ldots$ & 5.2 & 20 & 450 & 6.4 & 230 & 160 \\
\hline $\mathrm{CN}$.............................. & 5.9 & 10 & 430 & 6.3 & 20 & 270 \\
\hline
\end{tabular}


During the incubation period almost all the ammonium nitrogen applied in the fertilizer had been nitrified when the soil was kept dry. The only exception was ammonium sulphate, of whose ammonium nitrogen one third was left. Because the soil was extracted only once all applied nitrogen could not be recovered. Accordingly it seems likely that only very small amounts were lost or in other forms than ammonium or nitrate. The $\mathrm{pH}$ values followed the nitrification being the lower the more ammonium had been converted into nitrate. In wet soil no nitrification occurred. Part of the applied nitrate nitrogen was lost, probably by denitrification. No decrease in the $\mathrm{pH}$ was observed. Application of urea led to a $\mathrm{pH}$ rise probably because of its hydrolysis to ammonia.

\section{Field experiment, period 1972-73}

The grain and straw yields of spring wheat grown in 1972 and winter rye grown in 1973 are given in Table 1 . Without nitrogen fertilization winter rye gave better grain yields than spring wheat. The grain yield of spring wheat responded to the nitrogen application very clearly. The grain yields of nitrogenfertilized wheat were higher than those of rye. Irrespective of the treatment the rye gave more straw than the wheat.

In the first year raising the nitrogen rate from 75 to $150 \mathrm{~kg} / \mathrm{ha}$ significantly increased the grain yield. The straw yield was not affected. Broadcasting instead of placing the fertilizer seemed to reduce its effect on the grain yield a little, but not significantly. The different fertilizers did not differ in their effects.

In the second year when winter rye was grown, nitrogen fertilizers were given only to treatment $\mathrm{A}$ to reach the total amount of $150 \mathrm{~kg} / \mathrm{ha} \mathrm{N}$ in the two years of experiment for all treatments A, B and C. Nitrogen application to rye (treatment A) gave a marked yield increase. A slight residual effect of nitrogen given in the previous year (treatments B and C) seems likely. It was observed that the broadcasted nitrogen had had a somewhat larger residual effect than the placed one, but the difference was not statistically significant.

Ammonium sulphate given to rye was slightly superior to calcium nitrate in grain production. Urea gave more straw than the mixture of ammonium sulphate and calcium nitrate. Other treatments did not differ from either of these. The residual effect of broadcasted nitrogen on rye grain was greater when its source was calcium nitrate or calcium ammonium nitrate than urea or a mixture of ammonium sulphate or calcium nitrate.

The total grain and straw yields during the two years of wheat and rye responded clearly to the $150 \mathrm{~kg} / \mathrm{ha}$ of nitrogen given to these crops. The total grain yields were not significantly dependent on the year or the way the nitrogen was given. The total straw yields were higher when the applied nitrogen was divided for both years than when all was given in the first year. Different fertilizers did not differ in their effects.

The nitrogen contents in the grain and straw of spring wheat (1972) rose at least as much on the nitrogen rate being increased from 75 to $150 \mathrm{~kg} / \mathrm{ha}$ as when it was increased from nil to $75 \mathrm{~kg} / \mathrm{ha}$ (Table 2). It made no signifi- 
Table 1. Grain and straw yields of spring wheat (1972) and winter rye (1973), $\mathrm{kg} / \mathrm{ha}$ of D.M.

\begin{tabular}{|c|c|c|c|c|c|c|}
\hline \multirow{2}{*}{$\begin{array}{l}\text { Source of } \\
\text { fertilizer } N\end{array}$} & \multicolumn{2}{|c|}{ Spring wheat 1972} & \multicolumn{2}{|c|}{ Winter rye 1973} & \multicolumn{2}{|c|}{ Total $1972-73$} \\
\hline & $\begin{array}{l}\mathrm{kg} / \mathrm{ha} \mathrm{N} \text { in } \\
\text { fertilizer }\end{array}$ & straw & $\begin{array}{l}\mathrm{kg} / \mathrm{ha} \mathrm{N} \text { in } \\
\text { fertilizer grain }\end{array}$ & straw & $\begin{array}{l}\mathrm{kg} / \mathrm{ha} \mathrm{N} \text { in } \\
\text { fertilizer grain }\end{array}$ & straw \\
\hline
\end{tabular}

\section{Without $\mathrm{N}$}

$\begin{array}{llllllllll}\text { application } & 0 & 1650 & 1290 & 0 & 1870 & 2500 & 0 & 3520 & 3790\end{array}$

Treatment A

\begin{tabular}{llllllllll} 
1. Urea & $\left.75^{1}\right)$ & $2840^{\mathrm{a}}$ & $2510^{\mathrm{k}}$ & $\left.75^{2}\right)$ & $2620^{\mathrm{ab}}$ & $3570^{1}$ & 150 & $5460^{\mathrm{a}}$ & $6080^{\mathrm{k}}$ \\
2. AS & $\left.75^{1}\right)$ & $3080^{\mathrm{a}}$ & $2260^{\mathrm{k}}$ & $\left.75^{2}\right)$ & $2730^{\mathrm{b}}$ & $3450^{\mathrm{k} 1}$ & 150 & $5810^{\mathrm{a}}$ & $5710^{\mathrm{k}}$ \\
3. AS+CN & $\left.75^{1}\right)$ & $3030^{\mathrm{a}}$ & $2530^{\mathrm{k}}$ & $\left.75^{2}\right)$ & $2640^{\mathrm{ab}}$ & $3160^{\mathrm{k}}$ & 150 & $5560^{\mathrm{a}}$ & $5690^{\mathrm{k}}$ \\
4. CAN & $\left.75^{1}\right)$ & $2980^{\mathrm{a}}$ & $2350^{\mathrm{k}}$ & $\left.7^{2}\right)$ & $2620^{\mathrm{ab}}$ & $3240^{\mathrm{k} 1}$ & 150 & $5600^{\mathrm{a}}$ & $5590^{\mathrm{k}}$ \\
5. CN & $\left.75^{1}\right)$ & $3020^{\mathrm{a}}$ & $2350^{\mathrm{k}}$ & $\left.7^{2}\right)$ & $2520^{\mathrm{a}}$ & $3210^{\mathrm{k}}$ & 150 & $5540^{\mathrm{a}}$ & $5560^{\mathrm{k}}$ \\
\hline 1-5. Mean & $\left.75^{1}\right)$ & $2990^{\mathrm{A}}$ & $2400^{\mathrm{K}}$ & $\left.75^{2}\right)$ & $2630^{\mathrm{B}}$ & $3330^{\mathrm{L}}$ & 150 & $5620^{\mathrm{A}}$ & $5730^{\mathrm{L}}$
\end{tabular}

Treatment B

\begin{tabular}{llllllllll} 
1. Urea & $\left.150^{1}\right)$ & $3400^{\mathrm{a}}$ & $2410^{\mathrm{k}}$ & 0 & $1910^{\mathrm{a}}$ & $2710^{\mathrm{k}}$ & 150 & $5310^{\mathrm{a}}$ & $5120^{\mathrm{k}}$ \\
2. AS & $\left.150^{1}\right)$ & $3470^{\mathrm{a}}$ & $2530^{\mathrm{k}}$ & 0 & $1900^{\mathrm{a}}$ & $2600^{\mathrm{k}}$ & 150 & $5370^{\mathrm{a}}$ & $5130^{\mathrm{k}}$ \\
3. AS+CN & $\left.150^{1}\right)$ & $3470^{\mathrm{a}}$ & $2360^{\mathrm{k}}$ & 0 & $1920^{\mathrm{a}}$ & $2700^{\mathrm{k}}$ & 150 & $5390^{\mathrm{a}}$ & $5060^{\mathrm{k}}$ \\
4. CAN & $\left.150^{1}\right)$ & $3560^{\mathrm{a}}$ & $2550^{\mathrm{k}}$ & 0 & $1940^{\mathrm{a}}$ & $2500^{\mathrm{k}}$ & 150 & $5500^{\mathrm{a}}$ & $5050^{\mathrm{k}}$ \\
5. CN & $\left.150^{1}\right)$ & $3320^{\mathrm{a}}$ & $2330^{\mathrm{k}}$ & 0 & $2010^{\mathrm{a}}$ & $2690^{\mathrm{k}}$ & 150 & $5330^{\mathrm{a}}$ & $5020^{\mathrm{k}}$ \\
\hline 1-5. Mean & $\left.150^{1}\right)$ & $3440^{\mathrm{B}}$ & $2440^{\mathrm{K}}$ & 0 & $1930^{\mathrm{A}}$ & $2630^{\mathrm{K}}$ & 150 & $5370^{\mathrm{A}} 5070^{\mathrm{K}}$
\end{tabular}

Treatment C

\begin{tabular}{|c|c|c|c|c|c|c|c|c|c|}
\hline 1. Urea & $\left.150^{2}\right)$ & $3320^{\mathrm{a}}$ & $2280^{k}$ & 0 & $2060^{\mathrm{a}}$ & $2820^{k}$ & 150 & $5380^{\mathrm{a}}$ & $5100^{k}$ \\
\hline 2. AS & $\left.150^{2}\right)$ & $3420^{3}$ & $2250^{k}$ & 0 & $2190^{\mathrm{ab}}$ & $2890^{k}$ & 150 & $5610^{\mathrm{a}}$ & $5140^{k}$ \\
\hline 3. $\mathrm{AS}+\mathrm{CN}$ & $\left.150^{2}\right)$ & $3290^{\mathrm{a}}$ & $2270^{k}$ & 0 & $2070^{\mathrm{a}}$ & $2890^{k}$ & 150 & $5360^{\mathrm{a}}$ & $5160^{k}$ \\
\hline 4. $\mathrm{CAN}$ & $\left.150^{2}\right)$ & $3360^{\mathrm{a}}$ & $2270^{k}$ & 0 & $2260^{\mathrm{b}}$ & $2930^{k}$ & 150 & $5620^{\mathrm{a}}$ & $5200^{k}$ \\
\hline 5. $\mathrm{CN}$ & $\left.150^{2}\right)$ & $3260^{\mathrm{a}}$ & $2190^{k}$ & 0 & $2340^{\mathrm{b}}$ & $3090^{k}$ & 150 & $5600^{\mathrm{a}}$ & $5280^{k}$ \\
\hline 1-5. Mean & $\left.150^{2}\right)$ & $3330^{B}$ & $2250^{\mathrm{K}}$ & 0 & $2180^{A}$ & $2920^{\mathrm{KL}}$ & 150 & $5510^{A}$ & $5170^{\mathrm{KL}}$ \\
\hline \multicolumn{10}{|l|}{ A-C. Mean } \\
\hline 1. Urea & & $3190^{\mathrm{a}}$ & $2400^{k}$ & & $2200^{\mathrm{a}}$ & $3030^{k}$ & & $5390^{\mathrm{a}}$ & $5430^{k}$ \\
\hline 2. AS & & $3320^{\mathrm{a}}$ & $2350 \mathrm{k}$ & & $2270^{\mathrm{a}}$ & $2980^{k}$ & & $5590^{\mathrm{a}}$ & $5330^{k}$ \\
\hline 3. $\mathrm{AS}+\mathrm{CN}$ & & $3260^{\mathrm{a}}$ & $2390^{k}$ & & $2210^{a}$ & $2920^{k}$ & & $5470^{\mathrm{a}}$ & $5310^{k}$ \\
\hline 4. $\mathrm{CAN}$ & & $3300^{\mathrm{a}}$ & $2390^{k}$ & & $2270^{\mathrm{a}}$ & $2880^{k}$ & & $5570^{\mathrm{a}}$ & $5270^{k}$ \\
\hline 5. $\mathrm{CN}$ & & $3200^{\mathrm{a}}$ & $2290^{k}$ & & $2290^{\mathrm{a}}$ & $3000^{k}$ & & $5490^{\mathrm{a}}$ & $5290^{k}$ \\
\hline
\end{tabular}

1) The fertilizer was placed

2) , , broadcasted

The means of treatments $\mathrm{A}-\mathrm{C}$ as well as nitrogen sources within the same treatment are compared according to Tukey's test. Yields in each column not followed by a common letter differ significantly $(\mathrm{P}=0.95)$.

cant difference whether the fertilizer was placed or broadcasted. The nitrogen given to rye in 1973 likewise clearly increased the nitrogen content of its grain and straw. No residual effect of the nitrogen applied in 1972 could be observed. Different forms of nitrogen did not differ in this respect.

The uptake of nitrogen by spring wheat was clearly increased with increasing nitrogen fertilization (Table 3 ). The amount of nitrogen in the grain 
Table 2. Total nitrogen contents in grain and straw of spring wheat (1972) and winter rye (1973), $\mathrm{g} / \mathrm{kg}$ in D.M.

\begin{tabular}{llllll}
\hline \multirow{2}{*}{$\begin{array}{l}\text { Source of } \\
\text { fertilizer N }\end{array}$} & \multicolumn{2}{c}{ Spring wheat 1972} & & \multicolumn{2}{c}{ Winter rye 1973 } \\
\cline { 2 - 3 } & $\begin{array}{l}\mathrm{kg} / \text { ha N grain } \\
\text { fertilizer }\end{array}$ & straw & & $\begin{array}{l}\mathrm{kg} / \text { ha N grain straw } \\
\text { fertilizer }\end{array}$ \\
\hline
\end{tabular}

$\begin{array}{llllllll}\text { Without } \mathrm{N} \text { application } & \ldots & 0 & 21.7 & 6.7 & 0 & 14.8 & 2.7\end{array}$

Treatment A

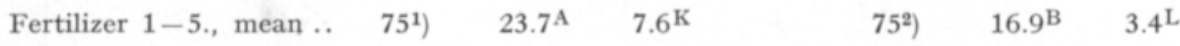

Treatment B

$\begin{array}{lllllll}\text { Fertilizer 1-5., mean .. } & \left.150^{1}\right) & 27.8^{\mathrm{B}} & 9.4^{\mathrm{L}} & 0 & 15.1^{\mathrm{A}} & 2.7^{\mathrm{K}}\end{array}$

Treatment C

$\begin{array}{lllllll}\left.\text { Fertilizer 1-5., mean .. } 150^{2}\right) & 27.0^{\mathrm{B}} & 9.0^{\mathrm{L}} & 0 & 15.5^{\mathrm{A}} & 2.7^{\mathrm{K}}\end{array}$

A-C. Mean

\begin{tabular}{|c|c|c|c|c|}
\hline 1. Urea $. . . \ldots \ldots \ldots \ldots \ldots \ldots . . . . . . .$. & $25.7^{\mathrm{a}}$ & $8.6^{\mathrm{k}}$ & $15.6^{\mathrm{a}}$ & $2.9^{k}$ \\
\hline 2. AS $\ldots \ldots \ldots \ldots \ldots \ldots \ldots \ldots \ldots \ldots \ldots \ldots$ & $25.9^{\mathrm{a}}$ & $8.5^{k}$ & $15.7^{\mathrm{a}}$ & $2.8^{\mathrm{k}}$ \\
\hline 3. $\mathrm{AS}+\mathrm{CN} \ldots \ldots \ldots \ldots \ldots$ & $26.0^{\mathrm{a}}$ & $9.0^{\mathrm{k}}$ & $15.7^{\mathrm{a}}$ & $2.9^{k}$ \\
\hline 4. CAN .................... & $26.5^{\mathrm{a}}$ & $8.4^{\mathrm{k}}$ & $16.0^{\mathrm{a}}$ & $3.0^{\mathrm{k}}$ \\
\hline 5. $\mathrm{CN}, \ldots \ldots \ldots \ldots \ldots \ldots \ldots \ldots \ldots \ldots \ldots$ & $26.6^{\mathrm{a}}$ & $8.9^{k}$ & $16.2^{\mathrm{a}}$ & $3.0^{\mathrm{k}}$ \\
\hline
\end{tabular}

1) The fertilizer was placed

2) , , broadcasted

The means of treatments $\mathrm{A}-\mathrm{C}$ as well as nitrogen sources within the same treatment are compared according to Tukey's test. Nitrogen contents in each column not followed by a common letter differ significantly $(\mathrm{P}=0.95)$.

yield rose in the same manner. The uptake after broadcasting was less than after placement of the fertilizers. The winter rye grown in the following year apparently utilized some of the residual fertilizer nitrogen, especially after having it broadcasted. The amount of nitrogen in the grain yield of rye responded to nitrogen fertilizers far less than did that of wheat. Thus, the total amount of nitrogen contained in the grain yields of both the crops was less in treatment A than B and C. In all these treatments the same amount of nitrogen had been given, but in treatment $\mathrm{A}$ half of it was given to rye while in the others the whole amount was given to spring wheat.

No marked differences could be observed between different fertilizers in their effects on the nitrogen uptake of spring wheat and winter rye. However, there was some tendency for the nitrate containing fertilizers to give a greater uptake than urea.

During the growth of the first crop, i.e. spring wheat in 1972, the accumulation of dry matter in the tops and the uptake of some nutrients were followed by sampling the plant stand at monthly intervals. The nitrogen was taken up in the main plot treatments as follows $(\mathrm{kg} / \mathrm{ha})$ : 
17. 6.

Without applied $\mathrm{N}$

$75 \mathrm{~kg} / \mathrm{ha} \mathrm{N}$ placed

150

150
17. 7.

13

$21^{\mathrm{A}}$

$27^{\mathrm{B}}$

$24^{\mathrm{B}}$
18.8

(grain + straw)

43

$89^{\mathrm{R}}$

$119^{\mathrm{T}}$

$110^{\mathrm{S}}$

The final nitrogen uptake was clearly raised by increasing the nitrogen rate from 75 to $150 \mathrm{~kg} / \mathrm{ha}$, though not so much as by the increase from 0 to $75 \mathrm{~kg} / \mathrm{ha}$. With broadcasting the uptake was less than with placing. All these differences were apparent already at the earlier samplings, but some of them were not significant.

There were no differences between the fertilizers in the crop's nutrient uptake except on 17.7. when $150 \mathrm{~kg} / \mathrm{ha} \mathrm{N}$ was placed. Ammonium sulphate then differed from the other fertilizers in the nitrogen and potassium uptake:

$\begin{array}{llllll} & \mathrm{kg} / \mathrm{ha} \text { D.M. } & \mathrm{g} / \mathrm{kg} \mathrm{N} & \mathrm{kg} / \mathrm{ha} \mathrm{N} & \mathrm{g} / \mathrm{kg} \mathrm{K} & \mathrm{kg} / \mathrm{ha} \mathrm{K} \\ \text { ammonium sulphate } \ldots \ldots \ldots . & 6290 & 21.2 & 133 & 24.0 & 155 \\ \text { others ......................... } & 5650-5890 & 19.6-20.1 & 113-115 & 21.1-22.2 & 127-129 \\ \text { significance of difference } & \text { not signif. } & \text { not signif. } & \text { P } 0.95 & \text { P } 0.95 & \text { P } 0.95\end{array}$

Table 3. Amount of nitrogen in grain and total uptake (grain + straw) in the years $1972-73, \mathrm{~kg} / \mathrm{ha}$ of $\mathrm{N}$.

\begin{tabular}{|c|c|c|c|c|c|c|c|c|c|}
\hline \multirow{2}{*}{$\begin{array}{l}\text { Source of } \\
\text { fertilizer } \mathrm{N}\end{array}$} & \multicolumn{3}{|c|}{ Spring wheat 1972} & \multicolumn{3}{|c|}{ Winter rye 1973} & \multicolumn{3}{|c|}{ Total $1972-73$} \\
\hline & $\begin{array}{c}\mathrm{kg} / \mathrm{ha} \mathrm{N} \text { in } \\
\text { fertilizer }\end{array}$ & grain & $\begin{array}{l}\text { grain }+ \\
\text { straw }\end{array}$ & $\begin{array}{l}\mathrm{kg} / \mathrm{ha} \mathrm{N} \text { in } \\
\text { fertilizer }\end{array}$ & grain & $\begin{array}{l}\text { grain }+ \\
\text { straw }\end{array}$ & $\begin{array}{c}\mathrm{kg} / \mathrm{ha} \mathrm{N} \text { in } \\
\text { fertilizer }\end{array}$ & grain & $\begin{array}{r}\text { grain }+ \\
\text { straw }\end{array}$ \\
\hline \multicolumn{10}{|l|}{ Without $\mathrm{N}$} \\
\hline application & 0 & 36 & 43 & 0 & 28 & 35 & 0 & 64 & 78 \\
\hline \multicolumn{10}{|l|}{ Treatment A } \\
\hline $\begin{array}{l}\text { Fertilizer } \\
1-5 ., \text { mean }\end{array}$ & $\left.75^{1}\right)$ & $71^{A}$ & $89^{\mathrm{K}}$ & $\left.75^{2}\right)$ & $44^{B}$ & $56^{\mathrm{L}}$ & 150 & $115^{\mathrm{A}}$ & $145^{\mathrm{K}}$ \\
\hline \multicolumn{10}{|l|}{ Treatmen B } \\
\hline $\begin{array}{l}\text { Fertilizer } \\
\text { 1-5., mean }\end{array}$ & $\left.150^{1}\right)$ & $96^{\mathrm{B}}$ & $119^{\mathrm{M}}$ & 0 & $29^{A}$ & $36^{\mathrm{K}}$ & 150 & $125^{B}$ & $155^{\mathrm{K}}$ \\
\hline \multicolumn{10}{|l|}{ Treatment C } \\
\hline $\begin{array}{l}\text { Fertilizer } \\
1-5 ., \text { mean }\end{array}$ & $\left.150^{2}\right)$ & $90^{\mathrm{B}}$ & $110^{\mathrm{L}}$ & 0 & $34^{A}$ & $42^{\mathrm{K}}$ & 150 & $124^{B}$ & $152^{\mathrm{K}}$ \\
\hline \multicolumn{10}{|l|}{$A-C .$, mean } \\
\hline 1. Urea & & $82^{\mathrm{a}}$ & $103^{k}$ & & $35^{\mathrm{a}}$ & $44^{k}$ & & $117^{a}$ & $147 \mathrm{k}$ \\
\hline 2. AS & & $86^{a}$ & $106^{k}$ & & $36^{\mathrm{ab}}$ & $44^{\mathrm{kl}}$ & & $122^{\mathrm{ab}}$ & $150^{\mathrm{k}}$ \\
\hline 3. $\mathrm{AS}+\mathrm{CN}$ & & $85^{\mathrm{a}}$ & $107 \mathrm{k}$ & & $35^{\mathrm{ab}}$ & $44^{k}$ & & $120^{\mathrm{ab}}$ & $151^{\mathrm{k}}$ \\
\hline 4. $\mathrm{CAN}$ & & $88^{\mathrm{a}}$ & $108^{k}$ & & $37 \mathrm{ab}$ & $45^{\mathrm{kl}}$ & & $125^{b}$ & $153^{k}$ \\
\hline 5. $\mathrm{CN}$ & & $86^{\mathrm{a}}$ & $106^{k}$ & & $37^{b}$ & $47^{1}$ & & $123^{\mathrm{ab}}$ & $153 \mathrm{k}$ \\
\hline
\end{tabular}

1) The fertilizer was placed

2) , broadcasted

The means of treatments $\mathrm{A}-\mathrm{C}$ as well as nitrogen sources within the same treatment are compared according to Tukey's test. Values in each column not followed by a common letter differ significantly $(\mathrm{P}=0.95)$. 
In the first two-year period the uptake of phosphorus and potassium was affected by the treatments only insofar as the yield was affected. This was also the case with calcium and magnesium which were determined in 1973 only. There was no difference between the fertilizers.

\section{Field experiment, period 1974-75}

In this period the same nitrogen rate was given to all plots except the controls. The winter wheat in 1974 received $75 \mathrm{~kg} / \mathrm{ha}$ nitrogen, the spring wheat in $1975100 \mathrm{~kg} / \mathrm{ha}$. The residues from earlier treatments did not cause any differences. Thus, only averages over the main-plot treatments are presented in Tables 4 and $\mathbf{5}$.

The nitrogen fertilization increased the grain and straw yields of both winter and spring wheat very clearly (Table 4). Only the straw yields of winter wheat were affected by differences in fertilizers. Ammonium sulphate was inferior to calcium ammonium nitrate. In addition, it was observed that nitrate tended to be superior to ammonium in general.

The nitrogen contents of winter wheat grain and straw as well as the uptake figures (Table 5) confirm the superiority of nitrate to ammonium in fertilizer. A similar tendency was observed in spring wheat 1975 , as well as in the total uptake of nitrogen by the four crops grown during the years $1972-75$, when totally $325 \mathrm{~kg} / \mathrm{ha}$ of fertilizer nitrogen had been given. Urea was rather similar to ammonium sulphate in this respect.

During this period the phosphorus and magnesium uptakes did not respond to the differences in the nitrogen source. In the year 1974 the following uptakes of potassium and calcium by winter wheat were recorded:

\begin{tabular}{lrrrrrr}
\multicolumn{2}{c}{ Without applied N } & Urea & AS & AS + CN & CAN & CN \\
$\mathrm{K}, \mathrm{kg} / \mathrm{ha}$ & 28.4 & 50.5 & 47.4 & 51.6 & 58.9 & 57.3 \\
$\mathrm{Ca}$, ? & 3.5 & 7.4 & 6.5 & 7.8 & 8.6 & 9.4
\end{tabular}

The change in the potassium uptake follows very closely the change in the straw yield. No differences in the potassium contents of grain or straw between the fertilizers could be observed. However, the change in the calcium uptake exceeded the change in the yield caused by a different source of nitrogen.

Table 4. Grain and straw yields of winter wheat (1974) and spring wheat (1975), kg/ha of D.M. Nitrogen application in $197475 \mathrm{~kg} / \mathrm{ha}$ and $1975100 \mathrm{~kg} / \mathrm{ha}$.

\begin{tabular}{|c|c|c|c|c|}
\hline \multirow{2}{*}{$\begin{array}{l}\text { Source of } \\
\text { fertilizer } \mathrm{N}\end{array}$} & \multicolumn{2}{|c|}{ Winter wheat 1974} & \multicolumn{2}{|c|}{ Spring wheat 1975} \\
\hline & grain & straw & grain & straw \\
\hline Without $\mathrm{N}$ application ... & 1710 & 1280 & 1940 & 1550 \\
\hline 1. Urea ...................... & $2440^{\mathrm{a}}$ & $2150^{\mathrm{k} 1}$ & $2760^{\mathrm{a}}$ & $2290^{k}$ \\
\hline 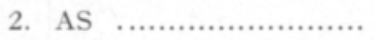 & $2530^{\mathrm{a}}$ & $1990^{k}$ & $2870^{\mathrm{a}}$ & $2340^{k}$ \\
\hline 3. $\mathrm{AS}+\mathrm{CN} \ldots \ldots \ldots \ldots \ldots . .$. & $2440^{\mathrm{a}}$ & $2200^{\mathrm{k} 1}$ & $2750^{\mathrm{a}}$ & $2260^{k}$ \\
\hline 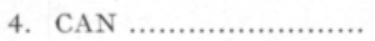 & $2540^{\mathrm{a}}$ & $2480^{1}$ & $2690^{\mathrm{a}}$ & $2290^{k}$ \\
\hline 5. $\mathrm{CN}, \ldots \ldots \ldots \ldots \ldots \ldots \ldots \ldots \ldots \ldots \ldots \ldots \ldots$ & $2530^{\mathrm{a}}$ & $2380^{\mathrm{k} 1}$ & $2800^{\mathrm{a}}$ & $2210^{k}$ \\
\hline
\end{tabular}

The yields in each column not followed by a common letter differ significantly $(\mathrm{P}=0.95)$ according to Tukey's test. 
Table 5. Nitrogen contents in grain and straw of winter wheat (1974) and spring wheat (1975) as well as nitrogen uptake by those crops and all four experimental crops in 1972-1975.

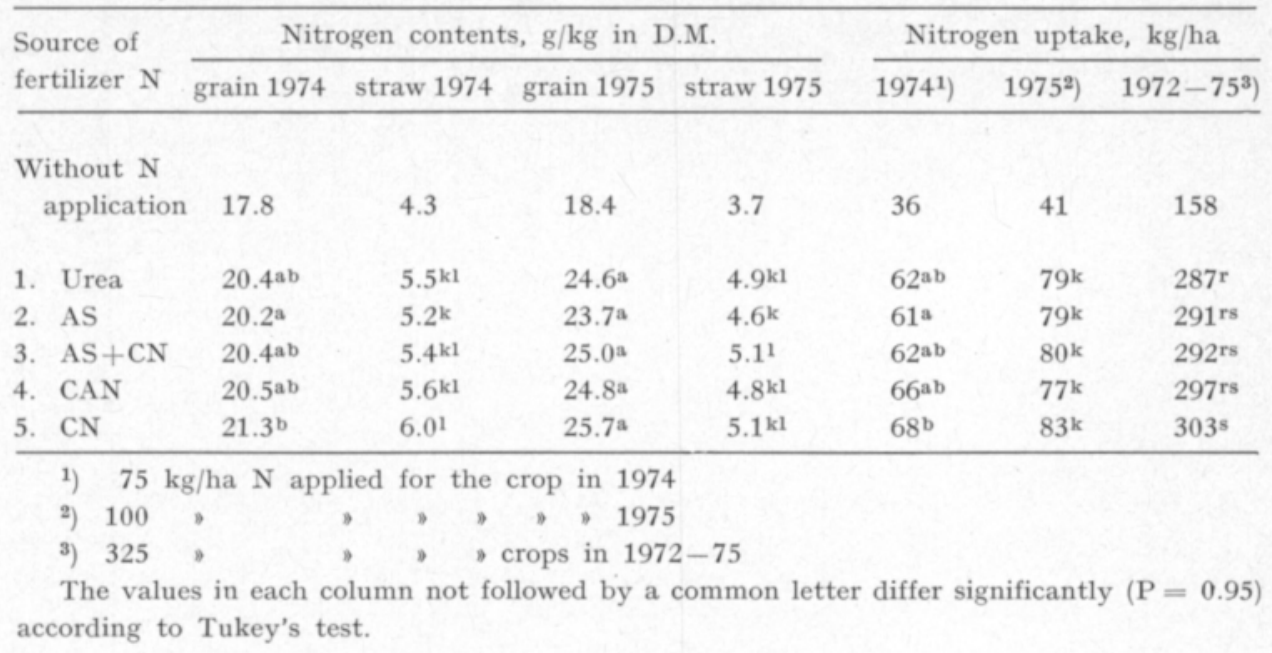

\section{Field experiment, year 1976}

The grain and straw yields of winter rye grown in the fifth year were increased by nitrogen fertilization (Table 6). It was most effective when given in late May. Application in early May did not differ from the application in late autumn the previous year. Only the grain yields differed, but not the straw yields. Between the fertilizers no differences were found.

Differences similar to those in the yields were observed in their nitrogen contents and nitrogen uptakes. The latest application gave grain richest in nitrogen. Also the uptake of nitrogen was highest when it was given late. There was no difference between the two earlier applications. At the first application in late autumn in the previous year, calcium nitrate gave a higher content of nitrogen in straw than ammonium sulphate or calcium ammonium nitrate. The uptake of nitrogen by plants fertilized with urea in late May was lower than when they were given calcium nitrate. Ammonium tended to be inferior to nitrate at both application times in May.

The uptake by the last crop of phosphorus, potassium, calcium and magnesium did not change with the different source of nitrogen.

\section{The field experiment as a whole}

Table 7 represents the total yields of grain and straw of the five experimental crops, their average nitrogen contents, the uptake of nitrogen over the whole five-year period and the total amount of nitrogen in grain yields harvested. The yields were very markedly increased by the $400 \mathrm{~kg} / \mathrm{ha}$ of nitrogen given during the five years. There were no differences in yields between the fertilizers. The nitrogen contents of both grain and straw were also increased by nitrogen applications. The superiority of nitrate to ammonium was evident. Urea did not deviate from the ammonium-containing fertilizers. Differences similar to those in the nitrogen contents existed also in the nitrogen amounts in grain yields and in the total uptakes of nitrogen. 
Table 6. Yields, nitrogen contents and nitrogen uptake of winter rye grown in 1976.

\begin{tabular}{|c|c|c|c|c|c|c|}
\hline \multirow{2}{*}{ Source of fertilizer $\mathrm{N}$} & \multicolumn{2}{|c|}{ Yield kg/ha D.M. } & \multicolumn{2}{|c|}{$\underline{\text { Nitrogen content } \mathrm{g} / \mathrm{kg} \text { in D.M. }}$} & \multicolumn{2}{|c|}{ Nitrogen uptake, $\mathrm{kg} / \mathrm{h}$} \\
\hline & grain & straw & grain & straw & grain & grain + strav \\
\hline Without $\mathrm{N}$ application..... & 2030 & 2950 & 15.4 & 3.0 & 31 & 40 \\
\hline 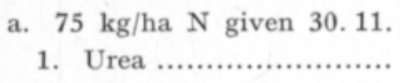 & $2750^{\mathrm{a}}$ & $4460^{k}$ & $16.4^{\mathrm{a}}$ & $4.0^{\mathrm{k} 1}$ & $45^{\mathrm{a}}$ & $62^{k}$ \\
\hline 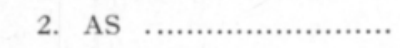 & $2780^{\mathrm{a}}$ & $4330^{\mathrm{k}}$ & $16.6^{\mathrm{a}}$ & $3.5^{\mathrm{k}}$ & $48^{\mathrm{a}}$ & $63^{k}$ \\
\hline 3. $\mathrm{AS}+\mathrm{CN} \ldots \ldots \ldots \ldots \ldots$ & $2810^{\mathrm{a}}$ & $4370^{\mathrm{k}}$ & $16.8^{\mathrm{a}}$ & $3.8^{\mathrm{k} 1}$ & $47^{\mathrm{a}}$ & $64 k$ \\
\hline 4. CAN ..................... & $2860^{\mathrm{a}}$ & $4450^{\mathrm{k}}$ & $16.3^{\mathrm{a}}$ & $3.3^{\mathrm{k}}$ & $47^{a}$ & $61^{k}$ \\
\hline 5. $\mathrm{CN}$........................ & $2680^{\mathrm{a}}$ & $4380^{\mathrm{k}}$ & $17.4^{\mathrm{a}}$ & $4.7^{1}$ & $47^{\mathrm{a}}$ & $66^{k}$ \\
\hline 1-5. Mean ..................... & $2800^{A}$ & $4400^{\mathrm{K}}$ & $16.7^{\mathrm{A}}$ & $3.9^{\mathrm{K}}$ & $47^{\mathrm{A}}$ & $63^{K}$ \\
\hline \\
\hline 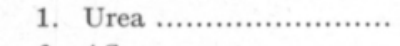 & $2940^{\mathrm{a}}$ & $4660^{k}$ & $16.0^{\mathrm{a}}$ & $4.0^{\mathrm{k}}$ & $47^{\mathrm{a}}$ & $65^{\mathrm{kl}}$ \\
\hline 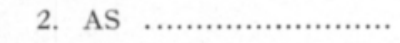 & $2810^{\mathrm{a}}$ & $4530^{k}$ & $16.0^{\mathrm{a}}$ & $3.3 \mathrm{k}$ & $45^{\mathrm{a}}$ & $60^{\mathrm{k}}$ \\
\hline 3. $\mathrm{AS}+\mathrm{CN} \ldots \ldots \ldots \ldots \ldots \ldots \ldots$ & $2890^{\mathrm{a}}$ & $4780^{k}$ & $17.3^{\mathrm{a}}$ & $4.2 \mathrm{k}$ & $50^{\mathrm{a}}$ & $70^{1}$ \\
\hline 4. CAN ...................... & $2920^{\mathrm{a}}$ & $4710^{k}$ & $16.4^{\mathrm{a}}$ & $4.1^{\mathrm{k}}$ & $48^{\mathrm{a}}$ & $67 \mathrm{kl}$ \\
\hline 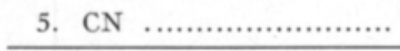 & $2850^{\mathrm{a}}$ & $4500^{k}$ & $16.8^{\mathrm{a}}$ & $3.9^{\mathrm{k}}$ & $48^{\mathrm{a}}$ & $65^{\mathrm{kl}}$ \\
\hline 1-5. Mean $\ldots \ldots \ldots \ldots \ldots \ldots$ & $2880^{A}$ & $4630^{\mathrm{K}}$ & $16.5^{\mathrm{A}}$ & $3.9 \mathrm{~K}$ & $47^{\mathrm{A}}$ & $65^{\mathrm{K}}$ \\
\hline \multicolumn{7}{|l|}{ c. $75 \mathrm{~kg} / \mathrm{ha} \mathrm{N}$ given 25.5 . } \\
\hline 1. Urea ...................... & $3150^{\mathrm{a}}$ & $4480^{k}$ & $17.9^{\mathrm{a}}$ & $3.6^{\mathrm{k}}$ & $56^{\mathrm{a}}$ & $72^{\mathrm{k}}$ \\
\hline 2. AS $\ldots \ldots \ldots \ldots \ldots \ldots \ldots \ldots \ldots \ldots \ldots \ldots \ldots$ & $3360^{\mathrm{a}}$ & $4470^{\mathrm{k}}$ & $17.5^{\mathrm{a}}$ & $4.0^{k}$ & $59^{a}$ & $77 \mathrm{kl}$ \\
\hline 3. $\mathrm{AS}+\mathrm{CN} \ldots \ldots \ldots \ldots \ldots \ldots$ & $3260^{\mathrm{a}}$ & $4310^{k}$ & $17.4^{\mathrm{a}}$ & $4.0^{\mathrm{k}}$ & $57^{\mathrm{a}}$ & $74 \mathrm{kl}$ \\
\hline 4. $\mathrm{CAN}$.......................... & $3330^{\mathrm{a}}$ & $4700^{k}$ & $18.3^{\mathrm{a}}$ & $4.0^{\mathrm{k}}$ & $61^{\mathrm{a}}$ & $79^{\mathrm{k} 1}$ \\
\hline 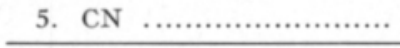 & $3480^{\mathrm{a}}$ & $4260^{k}$ & $18.5^{\mathrm{a}}$ & $4.2^{\mathrm{k}}$ & $64^{\mathrm{a}}$ & $82^{1}$ \\
\hline 1-5. Mean $\ldots \ldots \ldots \ldots \ldots \ldots$ & $3310^{\mathrm{B}}$ & $4440^{\mathrm{K}}$ & $17.9^{\mathrm{B}}$ & $3.9^{\mathrm{K}}$ & $59^{\mathrm{B}}$ & $77^{\mathrm{L}}$ \\
\hline \multicolumn{7}{|l|}{$a-c$. Mean } \\
\hline 1. Urea ...................... & $2950^{\mathrm{a}}$ & $4530^{\mathrm{k}}$ & $16.8^{\mathrm{a}}$ & $3.8^{\mathrm{k} 1}$ & $49 \mathrm{a}$ & $67 k$ \\
\hline 2. AS $\ldots \ldots \ldots \ldots \ldots \ldots \ldots \ldots \ldots \ldots \ldots \ldots \ldots \ldots$ & $3010^{\mathrm{a}}$ & $4440^{k}$ & $16.7^{\mathrm{a}}$ & $3.6^{\mathrm{k}}$ & $50^{\mathrm{a}}$ & $66^{k}$ \\
\hline 3. $\mathrm{AS}+\mathrm{CN} \ldots \ldots \ldots \ldots \ldots \ldots$ & $2990^{\mathrm{a}}$ & $4480^{k}$ & $17.1^{\mathrm{a}}$ & $4.0^{\mathrm{k} 1}$ & $51^{\mathrm{a}}$ & $69^{k}$ \\
\hline 4. CAN ...................... & $3040^{\mathrm{a}}$ & $4620^{k}$ & $17.0^{\mathrm{a}}$ & $3.8^{\mathrm{kl}}$ & $52^{\mathrm{a}}$ & $69^{k}$ \\
\hline 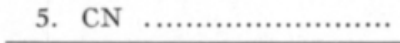 & $3000^{\mathrm{a}}$ & $4380^{k}$ & $17.5^{\mathrm{a}}$ & $4.3^{1}$ & $53 \mathrm{a}$ & $71^{k}$ \\
\hline
\end{tabular}

The means of treatments $\mathrm{A}-\mathrm{C}$ as well as nitrogen sources within the same treatment are compared accordin to Tukey's test. Values in each column not followed by a common letter differ significantly $(\mathrm{P}=0.95)$.

The uptake during the whole five-year period of phosphorus and potassium and during four years (1976-76) of magnesium did not change with the different sources of fertilizer nitrogen. The uptakes were on an average $(\mathrm{kg} / \mathrm{ha})$ :

$\begin{array}{lccc} & \text { P } & \text { K } & \begin{array}{c}\text { Mg } \\ \text { (4 years) }\end{array} \\ \text { Without applied N } & 38 & 146 & 10.1 \\ 400 \mathrm{~kg} / \mathrm{ha} \mathrm{N} \text { in } 5 \mathrm{yr} . & 55 & 251 & 15.7\end{array}$

The calcium uptake during $1973-76$ was $(\mathrm{kg} / \mathrm{ha})$ :

$\begin{array}{cccccc}\text { Without applied N } & \text { Urea } & \text { AS } & \text { AS }+ \text { CN } & \text { CAN } & \text { CN } \\ 19.6 & 31.9^{\mathrm{ab}} & 30.3^{\mathrm{a}} & 32.5^{\mathrm{abe}} & 35.5^{\mathrm{be}} & 34.8^{\mathrm{e}}\end{array}$

The uptake increased with increasing portions of nitrate in the fertilizer. Urea did not differ from the ammonium containing fertilizers. 
Table 7. Total yields and average contents of nitrogen as well as nitrogen uptake of the five cereal crops grown in 1972-76.

\begin{tabular}{|c|c|c|c|c|c|c|}
\hline \multirow{2}{*}{$\begin{array}{l}\text { Source of } \\
\text { fertilizer }\end{array}$} & \multicolumn{2}{|c|}{ Yield kg/ha D.M. } & \multicolumn{2}{|c|}{ Nitrogen content, g/kg in D.M. } & \multicolumn{2}{|c|}{ Nitrogen uptake, $\mathrm{kg} / \mathrm{ha}$} \\
\hline & grain & straw & grain & straw & grain & grain + straw \\
\hline $\begin{array}{l}\text { Without } \mathrm{N} \\
\text { application }\end{array}$ & 9200 & 9570 & 17.6 & 3.8 & 162 & 198 \\
\hline $\begin{array}{r}400 \mathrm{~kg} / \mathrm{ha} \mathrm{N} \\
\text { application }\end{array}$ & & & & & & \\
\hline 1. Urea & $13520^{\mathrm{a}}$ & $14410^{\mathrm{k}}$ & $21.0^{\mathrm{a}}$ & $4.8 \mathrm{kl}$ & $284^{\mathrm{a}}$ & $353^{k}$ \\
\hline 2. AS & $14000^{\mathrm{a}}$ & $14100^{k}$ & $20.8^{\mathrm{a}}$ & $4.6^{\mathrm{k}}$ & $291 \mathrm{ab}$ & $357 \mathrm{k}$ \\
\hline 3. $\mathrm{AS}+\mathrm{CN}$ & $13660^{\mathrm{a}}$ & $14250^{\mathrm{k}}$ & $21.2^{\mathrm{ab}}$ & $5.0^{1 \mathrm{~m}}$ & $290^{\mathrm{ab}}$ & $361 \mathrm{kl}$ \\
\hline 4. $\mathrm{CAN}$ & $13840^{\mathrm{a}}$ & $14660^{k}$ & $21.3^{\mathrm{ab}}$ & $4.8 \mathrm{kl}$ & $295^{\mathrm{ab}}$ & $366^{\mathrm{k} 1}$ \\
\hline 5. $\mathrm{CN}$ & $13820^{\mathrm{a}}$ & $14250^{\mathrm{k}}$ & $21.8^{\mathrm{b}}$ & $5.1^{\mathrm{m}}$ & $301^{\mathrm{b}}$ & $374^{1}$ \\
\hline
\end{tabular}

The values in each column not followed by a common letter differ significantly $(\mathrm{P}=0.95)$ according to Tukey's test.

\section{Soil $p H$ in the field experiment}

The soil $\mathrm{pH}$ was measured in samples taken 17.6. 1972 one month after the first application of nitrogen in different forms and 30.8.1976 at the end of the experiment. Averages of the main-plot treatments are given below as no differences between them existed:

\begin{tabular}{|c|c|c|c|}
\hline & $\begin{array}{c}17.6 .72 \\
\text { depth } 0-8 \mathrm{~cm} \\
\mathrm{pH}_{\mathrm{CaCl}_{2}}\end{array}$ & $\begin{array}{c}17.6 .72 \\
\text { depth } 8-25 \mathrm{~cm} \\
\mathrm{pH}_{\mathrm{CaCl}_{2}}\end{array}$ & $\begin{array}{c}30.8 .76 \\
\text { depth } 0-25 \mathrm{cn} \\
\mathrm{pH}_{\text {water }}\end{array}$ \\
\hline Without applied $\mathrm{N}$ & $6.3^{\mathrm{d}}$ & $6.1^{k}$ & $6.8^{\mathrm{rs}}$ \\
\hline 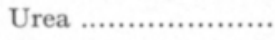 & $6.0^{\mathrm{ab}}$ & $6.2^{\mathrm{k}}$ & $6.7^{r}$ \\
\hline 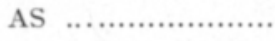 & $5.9^{\mathrm{a}}$ & $6.2^{\mathrm{k}}$ & $6.6^{r}$ \\
\hline $\mathrm{AS}+\mathrm{CN} \ldots \ldots \ldots \ldots \ldots$ & $6.1^{\mathrm{be}}$ & $6.2^{\mathrm{k}}$ & $6.6^{r}$ \\
\hline CAN $\ldots \ldots \ldots \ldots \ldots \ldots \ldots$ & $6.2^{\mathrm{ed}}$ & $6.3 \mathrm{k}$ & $6.7^{r}$ \\
\hline $\mathrm{CN}, \ldots \ldots \ldots \ldots \ldots \ldots \ldots$ & $6.3^{d}$ & $6.2^{\mathrm{k}}$ & $6.9^{\mathrm{s}}$ \\
\hline
\end{tabular}

At the sampling one month after application the differences were very clear in the uppermost soil layer of $\mathbf{8} \mathrm{cm}$. Ammonium sulphate and urea acidified the soil. The layer below $8 \mathrm{~cm}$ was not affected. At the end of the experiment the differences were similar, not larger in spite of the bigger amounts of fertilizer nitrogen given to the soil. However, at the final sampling the nitrogen given in the first four years hade been mixed with the whole plough layer of $25 \mathrm{~cm}$ while at the first sampling the applied nitrogen was distributed in the thin surface layer only. The amounts of nitrogen given to the soil until the first and final soil samplings were $150 \mathrm{~kg} / \mathrm{ha}$ and $400 \mathrm{~kg} / \mathrm{ha}$, respectively. At the final sampling subsoil samples were also taken. Average $\mathrm{pH}$ value was 6.5 without any differences due to treatments. 


\section{Discussion}

The fertilizers compared in this study contained a wide range of soluble forms of nitrogen: from pure ammonium to almost pure nitrate as well as urea. When incubated in wet soil taken from the experimental field the ammonium contained in any of these was not nitrified in 24 days. However, on the field the soil only very rarely remains for a longer period as wet as during this incubation. When the soil was kept dry during the incubation all the ammonium of the different fertilizers except some of the ammonium sulphate was nitrified in the 24 days. The slower nitrification of ammonium from ammonium sulphate depends, partly as least, on the large decrease in the $\mathrm{pH}$ after the application of this fertiiizer. Although a decrease of the $\mathrm{pH}$ in field conditions probably is always smaller and not so important, differences between fertilizers in their nitrification speed are still expected. Denitrification that was found to occur in wet soil may also account for the different behaviour of fertilizers in soil and for differences in their effects on crop growth.

The field experiment was performed on a sandy soil with cereals as experimental crops, which clearly responded to the nitrogen fertilizers. The amount of nitrogen given to the crops during the five-year period was in all $400 \mathrm{~kg} / \mathrm{ha}$. The average annual amount, $80 \mathrm{~kg} / \mathrm{ha} \mathrm{N}$, was higher than in the experiment reported by SAlonen and HonkavaAra (1970), but lower than in the experiments of PESsi et al. (1971 a, b). However, owing to the long experimental period of Salonen and HonkavaAra (1970), the total amount of nitrogen given during their experiment was higher than in the present one. All the experiments referred to above were performed on clay soils.

Although the differences in the behaviour of the fertilizers during the incubation were rather clear the crop growth was, in general, independent of the source of fertilizer nitrogen. The average differences over the whole experimental period were clearest in the nitrogen and calcium contents of the yields and in the soil $\mathrm{pH}$. Differences in grain or straw yields were found only in some years and with some methods of application. It was not possible to conclude whether it was different weather, different crop or different application method that accounted for this.

Ammonium nitrogen was on an average inferior to nitrate nitrogen but only slightly and not every year. In 1973 ammonium sulphate applied to winter rye gave an even larger yield increase than calcium nitrate. After ammonium application the yields mostly contained less nitrogen and calcium and, in some instances, were lower than when nitrate had been applied. The differences observed here were not as clear as those reported by SALONEN and HonkavaARa $(1954,1970)$. In their experiment ammonium was very much inferior to nitrate. The difference was reduced by liming the soil (SALONEN and HonkavaAra 1970). In the present experiment the soil was initially well limed and not even the plots given ammonium sulphate became so acid that the crop growth would have been affected. However, the acidity in the soil immediately surrounding the fertilizer granule may have increased appreciably reducing the availability to plant of the fertilizer. Between the calcium ammonium nitrate and the mixture of ammonium sulphate and cal- 
cium nitrate no difference was found, although the lime contained by the former led to the hypothesis that it would acidify the soil less than the latter.

The soil $\mathrm{pH}$ in the plough layer was decreased by $0.3-0.4$ units by the addition of $400 \mathrm{~kg} / \mathrm{ha}$ of ammonium nitrogen. This is in rather good agreement with figures given by Fogh (1972), Alessi and Power (1972) and Watson et al. (1973). All these experiments were on similarly textured soils but in different climatic conditions. Results of Salonen and HonkavaAra (1970) also agree quite well, although their experiment was performed on clay soil.

Urea was as good as or only slightly inferior to calcium nitrate. Similar results have been published by Devine and Holmes (1963 a, b), Pessi et al. (1971 b) and KLAusen (1974). In its effect on crop yield or on soil $\mathrm{pH}$ urea did not deviate significantly from ammonium sulphate.

A different method or time of fertilizer application did not cause any marked change in the behaviour of different fertilizers. One reason for this may be found in the fact that conditions in the years when the method and time were studied were favourable for the efficiency of all fertilizers. However, some obtained evidence pointed to calcium nitrate when broadcasted having had a larger residual effect than ammonium containing fertilizers or urea.

The differences in the effect of the fertilizers on crop were, even in extreme cases, very small. This was due partly to the fact that the soil was only very slightly acid. The acidity did in no case increase up to a detrimental level. If ammonium sulphate is applied continuously a marked decrease of soil $\mathrm{pH}$ may be expected. To prevent soil acidification due to ammonium containing fertilizers liming at regular intervals is necessary, otherwise crop growth and nitrogen fertilizer efficiency will decrease.

\section{REFERENCES}

Alessi, J. \& Power, J. F. 1972. Influence of nitrogen source and rate on growth of spring grain and soil pH. Agron. J. 64: 506-508.

Devine, J. R. \& Holmes, M. R. J. 1963 a. Field experiments comparing ammonium sulphate, ammonium nitrate, calcium nitrate and urea combine-drilled with spring barley. J. Agr. Sci. 61: 381-391.

_ \& Holmes, M. R. J. 1963 b. Field experiments on the value of urea as a fertilizer for barley, sugar beet, potatoes, winter wheat and grassland in Great Britain. J. Agr. Sci. 61: $391-396$.

FoGH, H. T. 1972. Aendringer i jordens $\mathrm{pH}$ og kalkbehov efter anvendelse af kalksalpeter, flydende vandfri ammoniak eller urea. Summary: Effect of nitrate of lime, anhydrous ammonia and urea on $\mathrm{pH}$ and lime requirement of the soil. Tidskr. Planteavl 76: $316-330$.

Klausen, P. S. 1974. Virkningen af foreskellige faste kvaelstofgødninger. Summary: The effect of different solid nitrogenous fertilizers. Tidskr. Planteavl 78:67-84.

Pessi, Y., Ylänen, M., Leskelä, A. \& Syvälahti, J. 1971 a. Autumn and winter application of nitrogen fertilizers on clay soils. J. Scient. Agric. Soc. Finl. 43: 76-85.

- , Syvälahti, J., Leskelä, A. \& Ylänen, M. 1971 b. Fertilizing experiments with anhydrous ammonia at Kotkaniemi. J. Scient. Agric. Soc. Finl. 43: 213-219. 
SAlonen, M. \& HonkavaAra, T. 1954. Karjanlannan ja väkilannoitteiden vaikutuksen vertailua. Summary: Results of a long term field experiment for the comparison of farmyard manure and different fertilizer combinations. Valt. Maatal.koetoim. Julk. 142.

- \& HonkavaAra, T. 1970. Karjanlannan ja väkilannoitteiden vaikutuksen vertailua II. Erilaiset lannoitukset ja kalkitus. Summary: The effects of farmyard manure and mineral fertilizers II. Different fertilizer combinations and liming. Ann. Agric, Fenn. 9: 336-342.

Watson, E. R., LApins, P. \& Greenwood, E. A. N. 1973. Changes in nitrogen and sulphur content and other soil properties after application of ammonium sulphate to grazed pastures in Western Australia. Austr. J. Exptl. Agr. Animal Husbandry 13: 69-74.

Ms received September 11, 1978.

\title{
SELOSTUS
}

\section{Nitraatti-, ammonium- ja ureatyppi vehnän ja rukiin lannoituksessa}

\author{
ANTTI JAAKKoLA \\ Maatalouden tutkimuskeskus, Maanviljelyskemian ja -fysiikan laitos, 01300 Vantaa 30
}

Viisivuotisessa kenttäkokeessa, joka sijaitsi hyvin kalkitulla hietamaalla, verrattiin keskenään viittä typpilannoitetta. Nämä olivat urea, ammoniumsulfaatti, kalkkisalpietari, oulunsalpietari ja ammoniumsulfaatista ja kalkkisalpietarista tehty seos. Peräkkäisinä vuosina viljellyt kasvit olivat kevätvehnä, syysruis, syysvehnä, kevätvehnä ja syysruis.

Keskimääräinen satotaso oli kaikkia lannoitteita käytettäessä sama, mutta yksittäisinä koevuosina todettiin joitakin eroja. Jyvien ja olkien typpi- ja kalsiumpitoisuudet olivat koko koekautena keskimäärin kalkkisalpietarilla lannoitetuilla alueilla korkeammat kuin ammoniumsulfaatilla lannoitetuilla. Muut lannoitteet eivät poikenneet kummastakaan näistä merkitsevästi. Kokeessa verrattiin myös hajalevitystä sijoituslannoitukseen ja tutkittiin erilaisia levitysaikoja ja lannoitetypen määriä. Näillä tekijöillä ei ollut vaikutusta lannoitteiden välisiin eroihin.

Lannoitteiden maan happamuutta lisäävä vaikutus väheni järjestyksessä: ammoniumsulfaatti, urea, ammoniumsulfaatin ja kalkkisalpietarin seos, oulunsalpietari. Kalkkisalpietari ei vaikuttanut maan happamuuteen. 